\title{
DOES PRODUCT DIVERSIFICATION AND EMPHASIS ON PROFITABILITY IN MICROFINANCING ALLEVIATE POVERTY?
}

\author{
Gemunu Nanayakkara and Lokman Mia*
}

Microfinancing institutions (MFIs) are likely to change their management policies and focus more on profitability and product diversification as they mature and expand in size because of a number of reasons, including among them, donor pressure and/or lack of funding to expand. The present study empirically tests whether such changes occur in MFls over time and how these changes affect their performance with regard to alleviating poverty.

Using data from a sample of $234 \mathrm{MFIs}$ from around the world, including in the Asia-Pacific region, the study analyses the relationships between age, size, product diversification and emphasis on profitability of MFIs and their impact on the performance in alleviating poverty. Multiple regression techniques and path analysis were used to test the above relationships. The main analysis was also repeated on MFIs in the Asia-Pacific region to assess the relevance of the findings of the main study to the Asia-Pacific region.

Results of the main analysis comprising the 234 MFIs in the sample show that MFIs expand in size with age. As MFls mature, they diversify to offer other services in addition to providing loans (product diversification). However, size acts as a mediating variable in this relationship. Ageing leads to more emphasis on profitability, which, in turn, leads to an

\footnotetext{
* Gemunu Nanayakkara, PhD (Tel: +61 7 37355243; e-mail: G. Nanayakkara@griffith.edu.au); and Lokman Mia, Professor, are from the Department of Accounting, Finance and Economics, Griffith Business School, Griffith University, Brisbane, Qld 4111, Australia. Dr. Nanayakkara is a lecturer at the Griffith University. His research interests include performance of microfinancing institutions and other non-profit organizations. Prof. Mia is a professor at Griffith University. His research interests include performance and organizational behaviour of profit and not-for-profit organizations. He has published papers in many high-level journals, including Accounting, Organizations and Society, Management Accounting Research and the British Accounting Review.
} 
improvement in the performance of MFIs in alleviating poverty. However, product diversification has a negative effect on the performance. The more recently established MFIs, which tend to focus only on providing loans, perform better than older ones (see figure 5).

The analysis, which was repeated only on the 70 MFIs in the Asia-Pacific region, show similar results to those of the main analysis with one exception. The results generally agree with the main findings that as MFIs grow in size with age, they focus more on profitability and adopt product diversification with this transformation. They also agree that emphasis on profitability leads to an improving performance with regard to alleviating poverty. However, the results show that product diversification by MFIs in the Asia-Pacific region has a positive impact on the performance compared with the negative effect found on the main sample.

The findings of this study confirm the shift to commercialism by MFIs over time by emphasizing profitability and product diversification. However, it also indicates that MFIs need be cautious when adopting product diversification strategies.

JEL classification: G21.

Keywords: Product diversification, poverty alleviation, performance, microfinancing.

\section{INTRODUCTION}

Microfinancing provides loans to the poor who are unable to get credit from commercial institutions, such as banks, because they do not have sufficient income and assets to offer as collateral. After the introduction of this concept by Professor Muhammad Yunus (2001) in the late 1970s, the number of microfinancing institutions (MFIs) has grown rapidly around the world. According to the State of the Microcredit Summit Campaign Report completed in 2012, by the end of 2010, there were 3,652 MFIs around the world serving more than 200 million poor people (Reed and Maes, 2012). The phenomenal growth of MFIs has been complemented by hundreds of millions of dollars of donor money injected into the sector. For example, the World Bank has granted US $\$ 1.29$ billion to MFIs over the years. During 2009 alone, it granted \$378 million (World Bank, 2009). 
Over the last three decades, MFIs have undergone a number of transformations. Two key areas in this regard pertain to "product diversification" and their "emphasis on profitability". In the early days, MFls took a non-commercial approach to achieve their objective of alleviation of poverty by only providing loans to the poor with the help of donor funds. However, during the 1990s, MFIs were compelled to take a more commercial focus due to lack of donor funding and donor pressure (Robinson, 2001; 2002; Fernando, 2006; Rogaly, 1996). The main argument in support of this is that donors alone do not have adequate funds to finance the global effort to alleviate poverty and hence MFIs need to generate their own surplus funds to expand and help more poor people. For example, the World Bank, one of the main donors to MFIs, developed a subsidy dependence index, which measured the extent to which a microfinancing institution depended on subsidies and by what percentage it needed to increase its interest rates to be self-funding. A transformation into different levels of commercialism has led some MFls to focus on profits and product diversification strategies, such as offering savings, insurance and other services to the poor in addition to loans (Aitken, 2010; Khan, 2010). However, these transformations have been criticized on the view that they cause MFIs to drive the borrowers into more debt and poverty (Bateman, 2010) and/or that they drive MFIs away from helping the "poorest of the poor" (Marcus, Porter and Harper, 1999; CGAP, 2001).

In this cross-sectional empirical study, the following is investigated:

(a) Whether changes in the management policies of MFIs in relation to "product diversification" and "emphasis on profitability" occur over time as MFIs mature (age) and increase in size;

(b) Whether these changes in the management policies contribute to improving the "performance" (measured in relation to alleviating poverty in a sustainable manner) of MFIs.

"Product diversification" is defined as diversifying into offering more services in addition to the primary core service of offering loans to the poor. MFIs that adopt "product diversification" strategies in their management policies tend to be offering other services, such as savings accounts and insurance products, to the poor, in addition to the primary activity of offering loans.

The "emphasis on profitability" is defined as the extent to which a microfinancing institution considers profitability as important in its management policies. This can vary across the spectrum from completely not-for-profit MFIs to highly commercial MFIs, such as banks. This variable is measured by the profit margin, as explained in section III, under Operationalization and measurement of variables. 
The "performance" of a microfinancing institution can have a number of different meanings. In this study, "performance" is defined as the ability of the microfinancing institution to "alleviate poverty in a sustainable manner". To assess this construct, four areas of the MFls operations are taken into account.

First, the increase in outreach (increase in the number of poor people assisted by the microfinancing institution) and the depth of outreach (how poor these customers are) is taken into account. These two factors are used to determine the effort of the microfinancing institution to reach and assist the poor. Then, the portfolio at risk (PAR), the ratio of bad loans to the total loan portfolio, is used as a proxy to measure the impact that the microfinancing institution has made on the poor people that it has assisted. A higher PAR indicates that a greater proportion of the poor who received assistance from MFIs are unable to repay their loans, which, in turn, worsens their financial situation. Consequently, the assistance has not helped to alleviate the poverty. A lower PAR indicates the opposite. Finally, it is argued that the operations of MFIs must be sustainable because, otherwise, their assistance to the poor would not be in a sustainable manner as defined in this study. Therefore, in this study, the "performance" in relation to alleviating poverty in a sustainable manner is measured by an index (Nanayakkara, 2012) consisting of these four factors, which are explained further in section II, under Age and size of microfinancing institutions, and section III, under Operationalization and measurement of variables.

Findings relating to the two research questions (a) and (b) above will contribute to the existing knowledge of the operations and transformations taking place in MFIs, which will help managers and policymakers to better manage the resources, currently totalling hundreds of millions of dollars, allocated to MFIs in the Asia-Pacific region and the rest of the world.

It may be noted that in relation to (a), no analysis has been done on what factors contribute to the changes in the management policies in relation to emphasis on profitability and product diversification, such as donor pressure or lack of funding. Thus far, studies have only focused on whether those changes do occur in MFIs when they mature and expand in size. This is a limitation in the study. The main reason for omitting this extension is difficulty in measuring and obtaining information on donor pressure and how the MFIs react to the pressure.

The findings of this study contribute to enhancing knowledge in the microfinancing area. First, no empirical studies that have looked at the changes that take place in MFIs when they transform over time and how those changes affect their performance in relation to alleviation of poverty. Second, the study extends the findings of past studies done in other industries to microfinancing. For example, a number of studies have looked at the relationship between age, size and product 
diversification in other industries (Donaldson, 1982; Dass, 2000; Dawley, Hoffman and Brockman, 2003; Geiger and Cashen, 2007). The validity of these findings in microfinancing has been tested. Third, also tested was whether Gibrat's Law explained under section II (Gibrat, 1931), which was later found not to be applicable to certain industries (Evans, 1987; Hall, 1987; Almus and Nerlinger, 1999), is applicable to microfinancing. The results indicate that Gibrat's Law is valid to microfinancing.

The next sections of this paper are organized as follows. Section II covers the literature review. This section looks at the issues surrounding the concept of "performance" in relation to microfinancing. Then, the literature relating to the effect of the independent variables on the performance is discussed to develop the hypotheses. Section III describes the statistical methods used in the analyses. The data collection, operationalization and measurement of variables and relationships between the independent variables are also explained in this section. Analysis of data and results are covered in section IV. Finally, a discussion of the results and the conclusions are given in section $\mathrm{V}$.

\section{LITERATURE REVIEW}

This section begins with a review of the literature that assesses the various methods used to measure the "performance" of MFIs and then argues the reasons for selecting the method adopted by Nanayakkara (2012). This is followed by the development of the hypotheses in relation to the research questions stated earlier.

\section{Performance of microfinancing institutions}

The fundamental aim of MFIs is to help and improve the quality of life of the poor by offering loans without security. This is quite different from that of commercial institutions, such as banks, in which profits take precedence over humanitarian or social factors. Therefore, the achievements or performance of MFls cannot be measured by indicators used to measure the performance of commercial enterprises, such as profit, increase in share value or return on investment.

Most of the research done shortly after MFls were introduced looked at their impact on poverty alleviation. These studies focused on measuring the improvement of various social and financial indicators of the poor borrowers as a result of receiving the loans from MFIs. Hulme and Mosley (1996) studied the improvement in income of 4,000 borrowers compared with control groups across four countries and concluded that microfinancing actually alleviates poverty. A number of social indicators, such as health and infant mortality, children's education, nutritional adequacy and attainment 
of food security, have been used to assess the performance of MFls in other studies (see Foundation for Development Corporation, 1992; Pitt and Khandker, 1996; Khandker, Khan and Khalily, 1995; Khandker and Khalily, 1996; ADB, 2000; Dunford, 2001; CGAP, 2002). These studies have all confirmed that microfinancing helps to improve the income and quality of life of the poor.

In a number of other studies, the focus had shifted from the impact on the poor borrowers to the efficient internal operations and delivery of service by MFIs. For example, Yaron (1992) found that a large number of MFIs were heavily dependent on subsidies and were not operating efficiently. This was also supported by various other studies (Christen, 1998; Adams, 1998). These studies implied the extent to which MFIs depend on subsidies as a measure of efficiency or "performance" of MFIs and that MFls needed to generate their own funds by taking a commercial approach. This concept was further extended and quantified by the World Bank when it created an index referred to as the "Subsidy Dependence Index" (SDI) for MFIs. This index measures the extent to which a microfinancing institution depends on subsidies and by what percentage it needs to increase its interest rates to be self-funding. The above studies highlight the importance of both external (impact on alleviating poverty) and internal (operational efficiency) factors when assessing the performance of MFIs. Both dimensions must be included when determining the "performance" of MFIs.

The Consultative Group to Assist the Poor (CGAP) is an international organization funded by more than 20 major donors that support microfinancing. The objective of CGAP is to develop and assist the microfinancing sector around the world. In its guidelines to donors, CGAP (2003) recommends five indicators to be used to assess the performance of a microfinancing institution: portfolio quality; financial sustainability; operational efficiency; outreach; and depth of outreach.

Nanayakkara (2012) has developed an index considering four dimensions to assess the performance of MFIs in relation to poverty alleviation. The first two are the "increase in outreach" (the increase in the number of poor people that the microfinancing institution has assisted over a given period) and the "depth of outreach" (how poor these people are). These two dimensions measure the efforts of MFls to alleviate poverty in its environment. The third dimension, PAR, indicates the loans that are granted by the microfinancing institution, which are in default now. Although this may be viewed as internal to the microfinancing institution, Nanayakkara (2012) argues that this is a proxy for measuring the impact on the life of the poor as a result of providing the loans. As explained above, a higher PAR indicates that a greater proportion of the poor who receive loans is buried more in debt and poverty. A lower PAR indicates the opposite. The fourth dimension is, "sustainability". Nanayakkara (2012) argues that it is very important that 
a microfinancing institution be sustainable in order to survive and continue to help alleviate poverty.

One of the main advantages of this index is that it is not bias against such variables as size, country and exchange rates and looks at the external impact made by the microfinancing institution in alleviating poverty, as well as internal operations. This index, given in section III, under Operationalization and measurement of variables, is used in this study to measure a microfinancing institution's "performance" in relation to alleviation of poverty.

\section{Age and size of microfinancing institutions}

Age and size are fundamental drivers that create changes in the activities of MFIs. For example, over time (age), MFIs gain knowledge and experiences in the local market pertaining to the type of potential services to offer, as well as become knowledgeable about the expectations of their donors (donor pressure on MFIs to generate their own funds by emphasizing profitability) and borrowers (demanding additional services for product diversification), which can trigger changes to their internal management policies and operations. As MFls expand, they gain access to more resources needed to implement these changes to their operations. Consequently, age and size serve as fundamental drivers of organizational change. Their impact on the performance is discussed below.

\section{Age and the performance of microfinancing institutions}

Several studies have looked at the relationship between the age and the growth rates of commercial companies. Studies conducted by Wagner (1995) and Glancey (1998) on manufacturing firms in Europe have shown that there is a negative relationship between the age and the rate of growth of companies. Using Australian data, Wijewardena and Tibbits (1999) have found that older firms expand at a slower rate compared with newer ones. These findings have also been confirmed by Almus and Nerlinger (1999) when they analysed the growth rates and age of German companies in a longitudinal study spanning over ten years.

However, there is no evidence in the current literature of any detailed studies relating to the relationship between the age and the performance of MFls. It is difficult to conclude whether the above findings relating to commercial organizations are applicable to MFIs in a similar manner. Commercial organizations have profit as one of their main objectives and obviously private investors set up new companies when they see a significant potential to reap profits with a high certainty in the immediate future. Therefore, in the early days, these companies are likely to make profits, which are used to help them to expand rapidly with the objective to recover their initial costs 
to achieve the scale of optimum efficiency. However, as time goes by, the initial environment can change and lucrative market opportunities may disappear as the result of competition and changes in other environmental factors. Hence, in the case of commercial organizations, young companies may perform better than mature companies.

However, in contrast, in the case of MFIs, upon inception, profitability is not the main objective. Most MFIs are funded by aid from donors. Therefore, the availability of donor funds (which may depend on lot of other factors) in the early stages may become a major governing factor in the expansion of relatively new MFIs. Another aspect that is worth noting is that because microfinancing is a relatively new area, most mature MFIs may have learned their best practices the hard way, by experimenting with new ideas and procedures. In the case of newly established MFIs, they have the opportunity to learn from the mistakes made by older ones. However, the relationship between age and performance in MFls has not been investigated in the literature. Following the previous studies in commercial organizations mentioned above, this study hypothesizes an inverse relationship between these two variables. Therefore, the first hypothesis to be tested empirically is stated as follows:

$\mathrm{H}_{1}$ : There is an inverse relationship between age and performance of an microfinancing institution.

\section{Size and the performance of microfinancing institutions}

The relationship between the firm size and growth is found in economic theory. Gibrat's Law states that there is no relationship between the size of a firm and its growth rate (Gibrat, 1931). However, a number of subsequent empirical studies have shown that Gibrat's Law does not apply to certain industries. For example, Evans (1987), using data from the United States of America, has shown that smaller firms have higher growth rates. This was further supported by Hall (1987), which used data relating to United States manufacturing companies. Similar findings have been reported in Germany (Almus and Nerlinger, 1999). The above studies are related to manufacturing industries.

However, research carried out in the Netherlands on the service industry has shown that Gibrat's Law is valid for the service industry (Audretsch and others, 2002). A study covering the service sector in Italy has shown mixed results with regard to Gibrat's law (Piergiovanni and others, 2002). The research looked at different business sectors in the hospitality industry and found that while growth was independent of size for some business sectors, Gibrat's Law did not apply for the other businesses that were included in the study. Therefore, the existing literature suggests that, 
contrary to Gibrat's Law, a relationship between growth and size may exist in some industry sectors.

Does Gibrat's Law apply to the microfinancing institutions, a service industry? In the current literature, no study answers this question. Generally, large organizations have the advantage of a good reputation, which helps them in many ways, including giving them easier access to external funds. They have more resources at their disposal and are less vulnerable to external unforeseen "shocks". Obviously, a larger size itself is a testimony to the fact that the organization has performed well and had expanded at some stage. However, as MFIs are quite different from commercial organizations, the size of a microfinancing institution cannot necessarily be equated to performance. When organizations become large, the span of control expands, which necessitates the introduction of rigid rules, manuals and procedures. Flexibility and being closer to the market to understand the needs of the poor plays a critical role in providing microfinancing services. Early attempts by donors to channel funds through large state banks failed because of the lack of the above factors (Schmidt and Zeitinger, 1994). Small organizations may be closer to the poor borrower, which enables them to have a better understanding of the type of services required by the target market. Owing to the narrow span of control, as a result of the smaller size, the systems and procedures of a small microfinancing institution may be more flexible than a larger microfinancing institution.

"The larger an organization the more formalized its behaviour" (Mintzberg and Quinn, 1998).

Data relating to a study comparing the customer base of nine banks that expanded to provide microfinancing services indicate some interesting results (Valenzuela, 2002). This study found that small MFls (defined as having fewer than 7,500 customers) have increased their customer base at a much higher rate than that of larger MFIs.

Therefore the second hypothesis to be tested in this study is stated as:

$\mathrm{H}_{2}$ : There is an inverse relationship between the size and the performance of a microfinancing institution.

\section{Management policy on profitability and product diversification}

\section{Product diversification}

While the management policy of some MFIs is to only focus on providing loans, others offer additional services, such as savings facilities and insurance, to the poor. There are advantages and disadvantages to providing these additional services. For 
example, in most countries, taking savings deposits requires adhering to stringent regulations and reporting requirements of respective central banks (or reserve banks) in the country. This increases the administration costs to MFIs (Vogel, 1998). However, the problem is that in the absence of a powerful regulatory authority, what guarantees the savings of the poor depositors? Whether the increase in administration costs is outweighed by the gains from deposits is not clear because unlike in commercial banks, the size of the deposits made by the poor is very small.

Vogel (1984) argues that offering savings facilities and other services helps MFIs to become financially viable. He cites successful MFIs, such as BRI (Indonesia), Banco Sol (Bolivia) and ACEP (Senegal), as real world cases to strengthen the argument. There is support for this argument from six case studies presented by Owens and Wisniwiski (1999), who concluded that poor people have both the capacity and the desire to save and that it is impediments in the policies and instruments that inhibit the mobilization of savings rather than the poor people's savings preferences. Savings also open a new avenue for MFls to access additional funds to expand their customer base. This study examines the impact of product diversification on the performance of MFls by comparing the performances of MFIs that provide only loans with MFIs that provide other services in addition to loans.

Therefore, the third hypothesis to be tested empirically can be stated as:

$\mathrm{H}_{3}$ : The performance of a microfinancing institution that provides savings facilities and other related services in addition to loans (product diversification) is better than the performance of a microfinancing institution that provides only loans.

\section{Emphasis on profitability}

The question of whether MFIs should focus on profits when the objective to alleviate poverty is not very clear. Obviously, emphasis on profitability would generate surplus funds for the microfinancing institution to expand its operations without relying on donors for subsidies. A number of scholars support this view (see Christen, 1998; Robinson, 1998; Schmidt and Zeitinger, 1994). However, the counter argument is that emphasis on profitability would result in MFls charging higher interest rates to the poor borrowers and the tendency of focusing on the "not-so-poor" borrowers at the expense of the "very poor" borrowers. Therefore, some argue that this would make it difficult for the "poorest of the poor" to access microfinancing services (Marcus, Porter and Harper, 1999). Case studies carried out in Latin America have shown that the not-for-profit MFIs concentrate on the very poor compared to MFIs with a commercial focus (CGAP, 2001). 
While the current debate looks at the pros and cons of a commercial focus (high emphasis on profitability) compared with a welfare focus (not-for-profit), it is not known which approach results in improving the overall performance of a microfinancing institution with regard to alleviating poverty, as defined in this study earlier and argued by Nanayakkara (2012). Under the commercial approach, profits generate surplus funds that enable a microfinancing institution to be sustainable and to expand its customer base. This, in turn, improves its ability to reach more poor people. Considering the above factors the fourth hypothesis that is tested empirically in this study can be stated as:

$\mathrm{H}_{4}$ : There is a positive relationship between the emphasis on profitability and the performance of a microfinancing institution.

\section{METHOD}

The statistical methods used for empirically testing the above hypotheses, operationalization and measurement of variables, the sample and data collection are covered in this section. The analysis that investigates the relationship between the variables mainly consists of two stages. In the first stage the above-mentioned four hypotheses are tested by using multiple regression. The second stage involves testing for any indirect or mediating effects among the independent variables. This is done by using the Baron and Kenny (1986) method, which is outlined in section III, under Testing for indirect and mediating effects.

\section{Hypotheses testing}

The four hypotheses developed in section II were tested using multiple regression analysis and the standard equation can be written as follows.

$$
\begin{aligned}
\text { Performance }= & \beta_{0}+\beta_{1} \text { (Age) }+\beta_{2} \text { (Size) }+\beta_{3} \text { (Providing only loans) } \\
& +\beta_{4} \text { (Emphasis on profitability) }+\epsilon
\end{aligned}
$$

Where $\beta_{1}$ - Regression coefficients $(i=0,1,2 \ldots n)$

$\epsilon$ - Standard error term.

If a particular regression coefficient $\left(_{i}\right)$ is zero in the formula (at a given confidence level which is taken as the standard 95 per cent in this study), then it can be concluded that the corresponding independent variable has no impact on the dependent variable and vice versa. This forms the basis of testing the four hypotheses. 


\section{Testing for indirect and mediating effects}

Although some of the independent variables may not have a direct impact on the dependent variable, they can have an indirect or mediating effect through other independent variables. This was tested by using the Baron and Kenny method (1986) outlined below.

\section{Baron and Kenny (1986) method for assessing mediating effects}

\section{Figure 1. Relationship of a mediating variable}

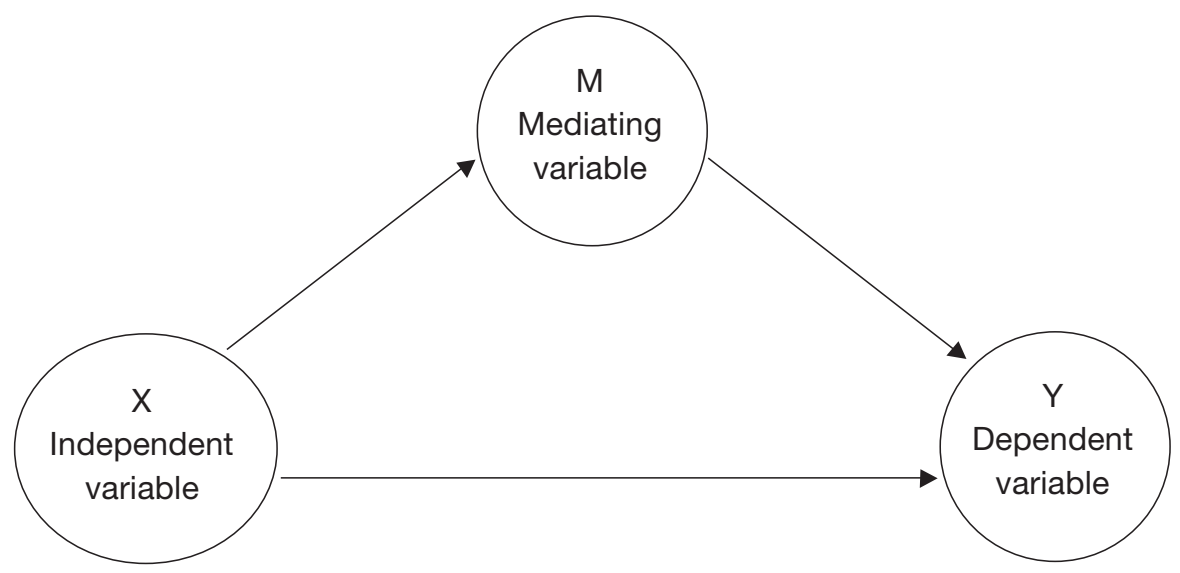

The relationships between the variables are shown in figure 1 where $M$ is the mediating variable. First the following two regressions are run.

$$
\begin{aligned}
& Y=\beta_{01}+\beta_{11} X+e_{1} \\
& M=\beta_{02}+\beta_{12} X+e_{2}
\end{aligned}
$$

where $\beta_{11}-$ is the impact of $X$ on $Y$

$$
\beta_{12}-\text { is the impact of } X \text { on } M \text {. }
$$

If $\beta_{11}$ is not equal to zero ( $X$ influences $Y$ ) and $\beta_{12}$ is also not equal to zero $(X$ influences $M)$ at $p<0.05$ confidence levels, then possible mediation effects through $M$ are tested by the following equation (note that if $\beta_{12}=0$ then $X$ does not influence $\mathrm{M}$, and hence there is no mediation). 


$$
Y=\beta_{03}+\beta_{13} X+\beta_{23} M+e_{3}
$$

where $\beta_{13}$ - is the impact of $X$ on $Y$ after controlling for $M$

$\beta_{23}-$ is the impact of $\mathrm{M}$ on $\mathrm{Y}$ after controlling for $\mathrm{X}$.

If $\beta_{13}=0$ and $\beta_{23}$ is not equal to zero at $p<0.05$ confidence level, then full mediation exists. That is total impact of $X$ on $Y$ shown by $\beta_{11}$ in the first regression flows through $\mathrm{M}$ to $\mathrm{Y}$.

If both $\beta_{13}$ and $\beta_{23}$ are not zero at $p<0.05$ confidence level, then partial mediation exists. That is $\mathrm{X}$ still has some direct effect on $\mathrm{Y}$ apart from what flows through $\mathrm{M}$ to $\mathrm{Y}$.

Using the above method developed by Baron and Kenny (1986), the indirect and mediating effects of the relationships discussed below were tested under this stage.

\section{$R_{1}$ - Relationship between the age, size and providing only loans}

It is argued at as MFls become older, they may grow in size. One of the reasons for this is that demand for microfinancing services far exceeds the supply (seller's market). For example, according to the State of the Microcredit Summit Campaign Report completed in 2012, only 200 million poor people are served by MFIs around the world compared with 900 million poor in the Asia-Pacific region alone.

There is also evidence that average size of firms increases with age in some industries. For example in the Hutchinson, Patrick and Walsh (2010) study, when kernel density estimates of the firm size distributions were plotted by age cohorts, as firms grow older, the size distribution shifts more to the right. This means that average firm size increases with age. This supports the similar result in the Cabral and Mata (2003) study, which analysed the firm size distributions with age of Portuguese manufacturing companies. Results of some other studies also show a positive significant correlation between firm size and age (Baker and Cullen, 1993; Yasuda, 2005).

It is also argued that both age and size of a microfinancing institution are related to product diversification. A number of studies indicate both age and size have positive effects on the management decision to diversify into other products. Dass (2000), who studied a sample of 555 companies in the United States over a range of industries from mining to manufacturing and services, found that firm size had a significant effect on diversification. Wheeler and others (1999) analysed the determinants of diversification of 3,986 hospitals in the United States into sub-acute 
care. They found that large hospitals or size had a positive effect on diversification. Studies by Donaldson (1982), Dawley, Hoffman and Brockman (2003) and Geiger and Cashen (2007) also showed that large firms tended to be more inclined to diversify than small ones. In the banking and finance area, Silverman and Castaldi (1992, p. 49) found that: "Larger community banks were significantly more interested in diversification strategies than their smaller counterparts".

With age, firms gain more experience and knowledge about the market and related other products that it could potentially offer. This forms the basis for companies to venture into new products and markets related to its existing status quo (Farjourn, 1994; Montgomery and Hariharan, 1991; Chang, 1996; Ingram and Baum, 1997). Therefore, age plays an important role in the ability and the potential of a firm to diversify into related products. Jiang (2006) analysed the determinants of diversification of 895 listed companies in China and found that both the age and size have a significant influence on diversification.

Considering the above, it can be concluded that age has a positive relationship with the size and that both the age and size have significant effects on the ability and the decision of MFls to diversify into other products, such as savings and insurance, in addition to loans. These relationships are shown in figure 2 and were tested using the Baron and Kenny (1986) method.

\section{$R_{2}-$ Relationship between age, emphasis on profitability and performance}

Various studies have indicated a trend among MFIs to start as not-for-profit organizations, such as non-governmental organizations (NGOs), and then transform gradually to commercial enterprises (Schmidt, 2010). Case studies carried out in a number of countries in Africa, South America and the Indian subcontinent have confirmed this "mission drift" of MFls (see Drake and Rhyne, 2002; Rhyne, 2001; Sriram, 2010; Khan, 2010). The reasons behind this trend are explained by Epstein and Yuthas (2010) as follows:

Like other social enterprises, dependence on funding can push MFIs to become more innovative and entrepreneurial (Mort, Weerawarden and Carnegie, 2003), or it can make them behave more like market-driven corporations (Eikenberry and Kluver, 2004). As the microfinance industry matures, funders are becoming more demanding in their expectations for effective investment of these funds and for clear demonstrations of social impact. Such institutional changes have pushed non-profits toward a corporate approach (Bruck, 2006). 
Considering the above, it can be argued that as MFls mature, they tend to focus more on profitability. Since, it has already been hypothesized that age and emphasis on profitability can have a direct impact on performance, the relationship among these three variables can be shown in figure 4 and was tested using the Baron and Kenny (1986) method described above.

The analysis and results of the above models tested under the Baron and Kenny method are discussed in section IV, under Analysis of mediating effects.

\section{Operationalization and measurement of variables}

The variables in the hypotheses at the conceptual level have to be operationalized and measured prior to using them to run the regressions to test the hypotheses. This is discussed below.

\section{Performance}

The performance $\left(\mathrm{P}^{\star}\right)$ is operationalized and measured by an indicator comprising the four dimensions as follows. This indicator measures the MFIs performance in relation to "alleviation of poverty in a sustainable manner" as explained previously (Nanayakkara, 2012).

$$
P^{*}=C^{*}+S^{*}+\left[1-D^{*}\right]+\left[1-P A R^{*}\right]
$$

Where $\mathrm{P}^{\star}-$ Performance of the MFI during the period under study

$$
\begin{aligned}
& C^{*} \text { - Increase in outreach } \\
& D^{*}-\text { Depth of outreach } \\
& P^{*} R^{*} \text { - Portfolio at risk greater than } 30 \text { days, and } \\
& S^{*} \text { - Sustainability. }
\end{aligned}
$$

\section{Age}

Age relates to the number of years that the microfinancing institution has operated from the time of inception until the beginning of the year in which its performance was assessed in the study.

\section{Size}

The number of employees is argued as the best proxy for determining the size of a microfinancing institution. This is because microfinancing is not a machine- 
intensive high-tech operation, but, instead, entails carrying out tasks requiring a number of employees (for example, screening loan applications, disbursement of loans and collection of repayments). Therefore, it is reasonable to expect the number of employees to rise when the scale of operation and the size of MFls increase.

\section{Product diversification}

This was measured by categorizing MFIs into two groups using dummy variables, as follows:

LOANS - MFIs that provide only loans (if only loans then value $=1$, otherwise
zero)

SAVINGS - MFIs that provide savings and other related services in addition to loans. These are MFls that have gone into product diversification (if loans and other services then value $=1$, otherwise zero).

SAVINGS (product diversification) is taken as the base variable and therefore only LOANS is included in the regression.

\section{Emphasis on profitability}

The emphasis placed by MFIs on profitability is operationalized and measured by the profit margin made by each microfinancing institution. It can be argued that MFIs that place greater emphasis on profitability have higher profit margins. For example, the profit margin can be easily manipulated by the interest rate charged on the loans by the microfinancing institution. Unlike commercial banks, which are subject to market forces and stiff competition, interest rates are almost totally under the control of MFIs, owing to lack of competition and the high demand compared with the supply of microfinancing services (a seller's market). Therefore, MFIs that place greater emphasis on profitability are likely to have higher profit margins because they can charge higher interest rates.

The profit margin for MFIs is defined by CGAP (2003) as the ratio of net operating income to operating revenue.

\section{Sample and data collection}

Data relating to the performance of MFIs were collected from the CGAP-funded mix-market database. The sample size totalled $234 \mathrm{MFls}$ across 63 countries, including countries in the Asia-Pacific region. The sample also included all types of MFIs (NGOs, cooperatives/credit unions, rural banks, non-bank financial institutions and banks) for which there were data required for the study in the database. The 
performance varied from -4.56 to 6.8 , with an average of 2.8. The size measured by the number of employees ranged from 4 to 18,926. The average size was 306 employees. The average age of MFIs in the sample was 10 years, with the newest one operating only one year and the oldest one functioning for 40 years. Therefore, there was adequate variance and the sample size in the variables was sufficient to support generalizing and extending the findings to all types of MFIs in the Asia-Pacific region and in the rest of the world.

\section{DATA ANALYSIS AND RESULTS}

\section{Data screening}

The data were first screened to assess the distributions, outliers and missing values. This resulted in the elimination of six cases from the data sample. The distributions of the variables "age" and "size" were positively skewed. This was overcome by creating two additional variables (LAGE \& LSIZE) doing a log transformation as follows.

$$
\begin{aligned}
& \operatorname{LAGE}=\log _{\mathrm{e}}(\text { Age }) \\
& \text { LSIZE }=\log _{\mathrm{e}}(\text { Size })
\end{aligned}
$$

The distribution of "performance" and "profit margin" did not show any skewness and hence, a log transformation was not required.

\section{Hypotheses testing}

This section describes the analysis undertaken to test the four hypotheses developed in section II. All calculations relating to statistics were completed using the SPSS Version 20 software. The correlation matrix is given in table 1.

The results of the regression (ref equation (1) in section III, under Hypotheses testing), which test the four hypotheses, are given in table 2 . The significance levels relating to the standardized coefficients of the independent variables shown in table 2 indicate that "emphasis on profitability", "providing only loans" and "age" have a direct significant effect on the "performance" of MFIs at a 95 per cent confidence interval ( $\left.{ }^{*} p<0.05\right)$. However, the effect of "size" on the performance of MFls is not statistically significant $(p>0.05)$. Therefore, hypothesis $\mathrm{H}_{2}$ is not supported. 
Table 1. Correlation matrix

\begin{tabular}{lccccc}
\hline \multicolumn{1}{c}{ Variables } & Performance & $\begin{array}{c}\text { Emphasis } \\
\text { on } \\
\text { profitability }\end{array}$ & $\begin{array}{c}\text { Providing } \\
\text { only } \\
\text { loans }\end{array}$ & Size & Age \\
\hline 1. Performance & 1.00 & & & & \\
2. Emphasis on profitability & $0.29^{\star \star}$ & 1.00 & & & \\
3. Providing only loans & $0.14^{*}$ & -0.08 & 1.00 & & \\
4. Size & -0.21 & 0.01 & $-0.23^{\star \star}$ & 1.00 & 1.00 \\
5. Age $^{\mathrm{a}}$ & $-0.08^{\star}$ & $0.24^{\star \star}$ & $-0.16^{\star}$ & $0.36^{\star \star}$ & \\
\hline
\end{tabular}

Notes: $\quad{ }^{a}$ Log transformations were used.

Sample $\mathrm{N}=234$; cross-sectional data.

${ }^{*} \mathrm{p}<0.05,{ }^{\star *} \mathrm{p}<0.01$.

Table 2. Regression results ${ }^{a}$ of equation (1)

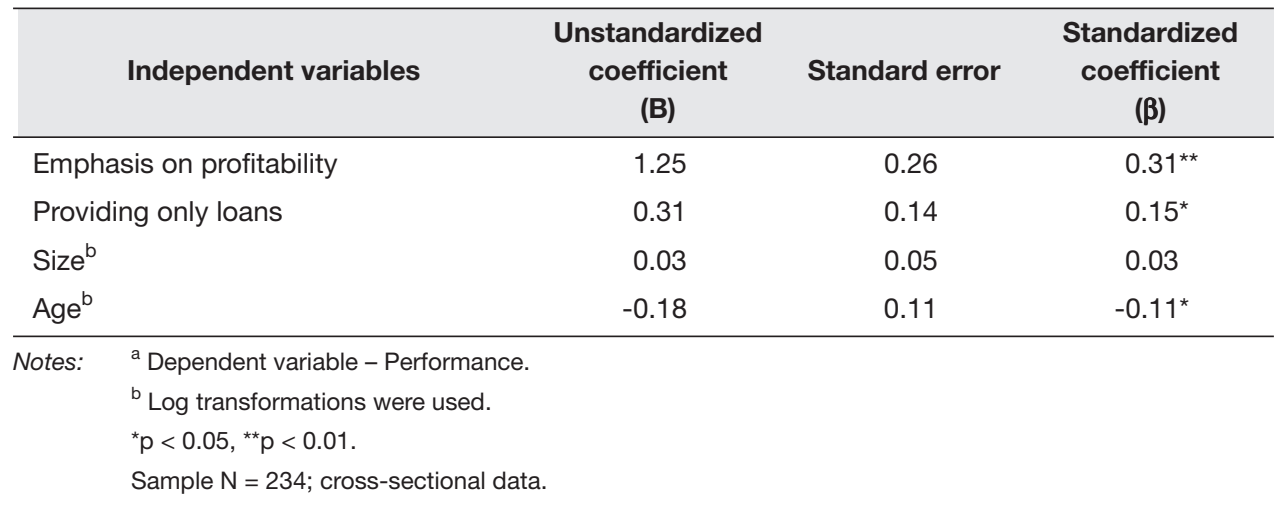

As shown in table 2, the sign of the regression coefficient for "age" is negative. This indicates that there is a significant inverse relationship between the age and the performance of MFIs. Therefore, hypothesis $\mathrm{H}_{1}$ is supported.

The sign of "emphasis on profitability" on "performance" is positive, i.e. MFIs perform better if they focus on profitability. In other words, taking a "commercial" approach rather than a "welfare" approach enables MFIs to perform better in alleviating poverty. Hence, the hypothesis $\mathrm{H}_{4}$ is supported.

The impact of "providing only loans" on the performance is significant $(p<0.05)$. However, the sign of the regression coefficient is positive, which is unexpected. This means that MFIs that only focus on providing loans (no product 
diversification) perform better than those that have diversified to provide other services in addition to loans. This is opposite to what was hypothesized in $\mathrm{H}_{3}$ and challenges the findings of previous studies conducted in other industries.

The above results are discussed in detail under section V.

\section{Analysis of mediating effects}

This section analyses the mediating effects that were outlined in section III, under Testing for indirect and mediating effect.

$R_{1}$ - Relationship between age, size and providing only loans

The relationship between age, size and providing only loans discussed in section III, under Testing for indirect and mediating effect, is shown in figure 2.

\section{Figure 2. Relationship $\mathbf{R}_{1}$}

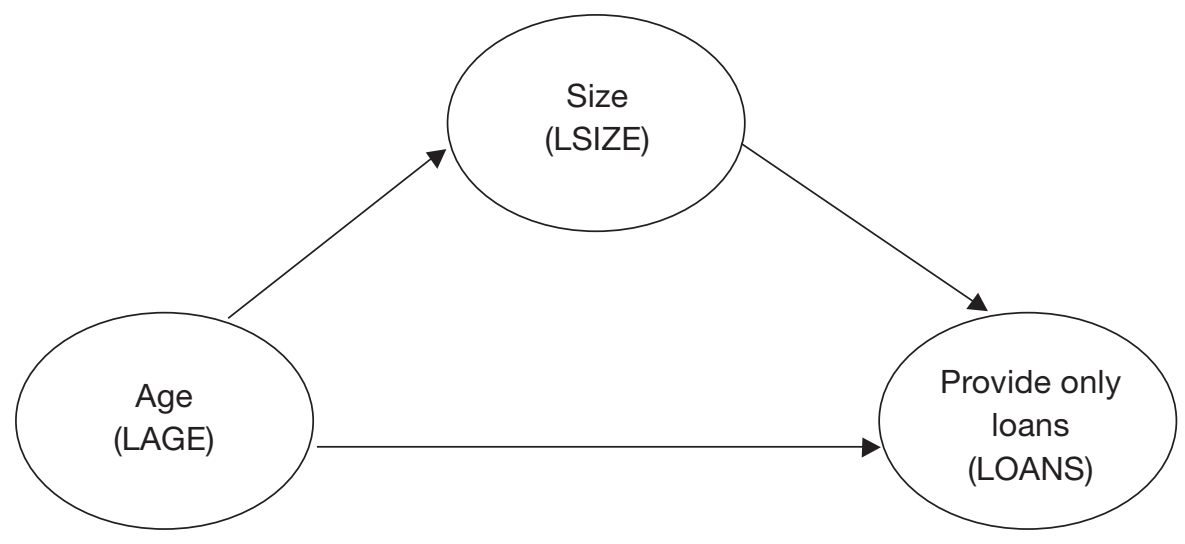

First, regressions were run on "providing only loans" and "size" as dependent variables and age as the independent variable. Then, to test the mediating effect, a regression is run on "providing only loans" as the dependent variable and both "age" and "size" as independent variables (Baron and Kenny method explained in section III, under Testing for indirect and mediating effect). The outputs of these regressions are shown in table 3.

In the results of the first two regressions shown in table 3 , "age" has statistically significant relationships with "size" and "providing only loans" ${ }^{* *} p<0.01$ 


\section{Table 3. Relationship between age, ${ }^{\mathrm{a}}$ size ${ }^{\mathrm{a}}$ and providing only loans}

\begin{tabular}{llc}
\hline \multicolumn{1}{c}{ Regression models } & $\boldsymbol{\beta}$ & Value of $\boldsymbol{\beta}_{\mathrm{ij}}$ \\
\hline Providing only loans $=\beta_{01}+\beta_{11}$ Age $+\mathrm{e}_{1}$ & $\beta_{11}$ & $-0.16^{\star *}$ \\
Size $=\beta_{02}+\beta_{12}$ Age $+\mathrm{e}_{2}$ & $\beta_{12}$ & $0.36^{\star *}$ \\
Providing only loans $=\beta_{03}+\beta_{13}$ Age $+\beta_{23}$ Size $+\mathrm{e}_{3}$ & $\beta_{13}$ & -0.11 \\
& $\beta_{23}$ & $-0.19^{\text {** }}$ \\
\hline
\end{tabular}

Notes: ${ }^{a}$ Log transformations were used.

${ }^{*} \mathrm{p}<0.05,{ }^{* *} \mathrm{p}<0.01$.

Sample N = 234; cross-sectional data.

for $\beta_{11}$ and $\left.\beta_{12}\right)$. The sign of the coefficient for $\beta_{12}$ is positive. The positive relationship between those two variables means that when MFIs mature, they grow in size, which is expected. The relationship between "providing only loans" and "age" is negative $\left(\beta_{11}<0\right)$. This indicates that as MFls mature, they do not "provide only loans"; they also provide other services. In other words, mature MFIs go into product diversification.

Because "age" has a significant positive relationship with "size" (table 3, second regression), it is necessary to test whether the total or part of the effect that age has on product diversification is due to its positive relationship with "size". That is whether "size" acts as a mediating variable in the relationship between "age" and "providing only loans". This is analysed in the third regression when the effect of "age" on "providing only loans" is controlled for the effect of "size" by including both "age" and "size" as independent variables (table 3, third regression).

This regression shows that there is a highly significant negative effect of "size" on "providing only loans" ( ${ }^{* *} p<0.01$ for $\beta_{23}$ ). This means that large MFIs do not just "provide only loans" and diversify into other services (product diversification).

The third regression also shows that when "size" is included, the relationship between "age" and "providing only loans" is not significant $\left(p>0.05\right.$ for $\beta_{13}$ ). Therefore, full mediation through "size" exists (Baron and Kenny, 1986). In other words, mature MFIs grow in size and diversify into other products in addition to providing loans. The relationship between these three variables, as suggested by the results given in table 3 , is shown in figure 3 . 
Figure 3. Relationship between age, size and providing only loans

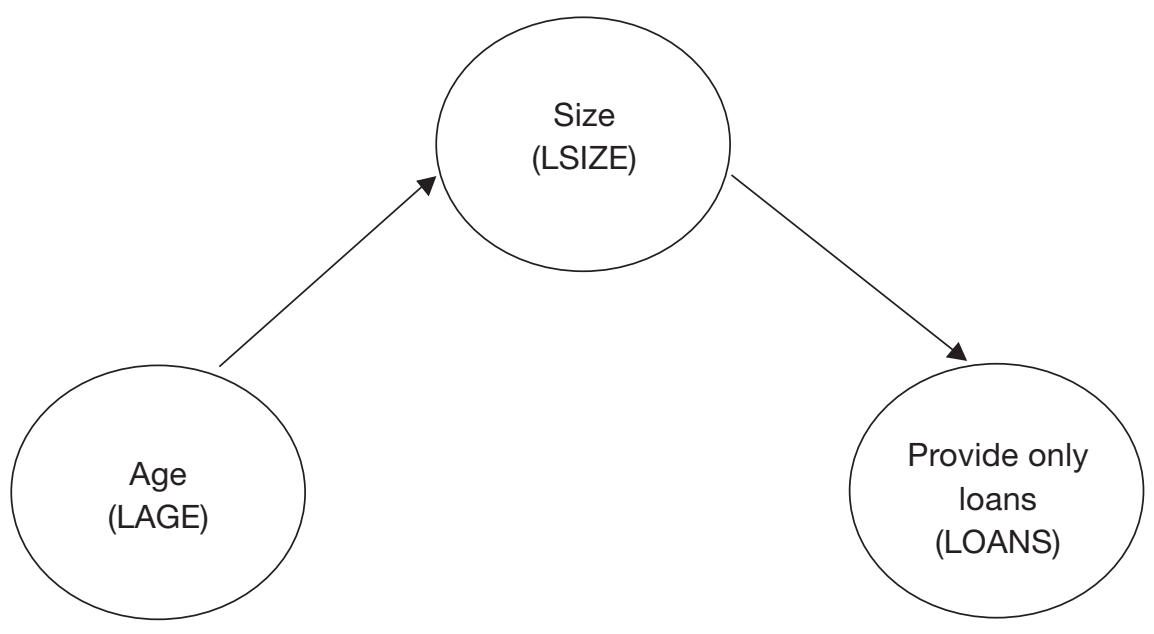

$R_{2}$ - Relationship between age, emphasis on profitability and performance

The relationship between age, emphasis on profitability and performance, as discussed in section III, under Testing for indirect and mediating effect, is shown in figure 4 .

Figure 4. Relationship R2

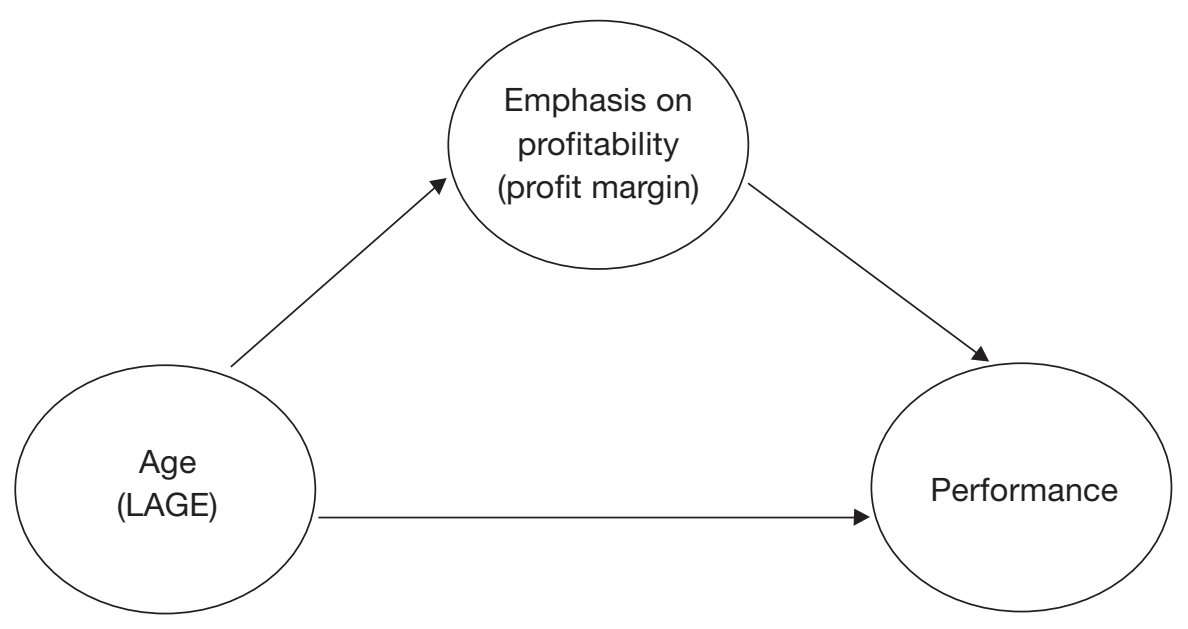


The results of the three regressions were run to test the mediating effect of "emphasis on profitability" between "age" and performance using the Baron and Kenny (1986) method, given in table 4.

\section{Table 4. Relationship between age, ${ }^{a}$ emphasis on profitability and performance}

\begin{tabular}{llc}
\hline \multicolumn{1}{c}{ Regression models } & $\boldsymbol{\beta}$ & Value of $\boldsymbol{\beta}_{\mathrm{ij}}$ \\
\hline Performance $=\beta_{01}+\beta_{11}$ Age $+\mathrm{e}_{1}$ & $\beta_{11}$ & $-0.08^{\star}$ \\
Emphasis on profitability $=\beta_{02}+\beta_{12}$ Age $+\mathrm{e}_{2}$ & $\beta_{12}$ & $0.24^{\star *}$ \\
Performance $=\beta_{03}+\beta_{13}$ Age $+\beta_{23}$ Emphasis on profitability $+\mathrm{e}_{3}$ & $\beta_{13}$ & $-0.12^{\star}$ \\
\hline
\end{tabular}

Notes: $\quad{ }^{a}$ Log transformations were used.

${ }^{\star} p<0.05,{ }^{\star *} p<0.01$.

Sample $\mathrm{N}=234$; cross-sectional data.

The first regression in table 4 shows that "age" has a significant negative effect on performance ( ${ }^{*} \mathrm{p}<0.05$ and $\beta_{11}<0$ ). This means that young MFIs perform better than older ones, which supports the hypothesis $\mathrm{H}_{1}$, as shown earlier. The second regression shows that "age" has a significant positive impact on "emphasis on profitability" ("* $p<0.01$ and $\beta_{12}>0$ ). This supports the argument discussed in section III, under Testing for indirect and mediating effect, that mature MFIs place greater emphasis on profitability.

In the third regression, when the mediating effect of "emphasis on profitability" is tested, "age" still has a significant negative effect on performance ( $\mathrm{p} p<0.05$ and $\left.\beta_{13}<0\right)$. Therefore, it can be concluded that any mediating effect of "emphasis on profitability" on the relationship between "age" and "performance" is insignificant, although there is a statistically significant relationship between age and emphasis on profitability.

\section{Relevance of the main results to the Asia-Pacific region}

The above analysis was repeated on the data relating to $70 \mathrm{MFIs}$ in the sample that are located in the Asia-Pacific region. This was carried out to compare the relevance of the findings that were revealed in the main analysis to MFIs operating in the Asia-Pacific region. The Comparison of the results of Asia-Pacific countries analysis with those of the main sample covering all the countries are given in tables 5 , 6, 7 and 8 . The shaded columns relate to the results of the analysis conducted on MFIs in the Asia-Pacific region. 


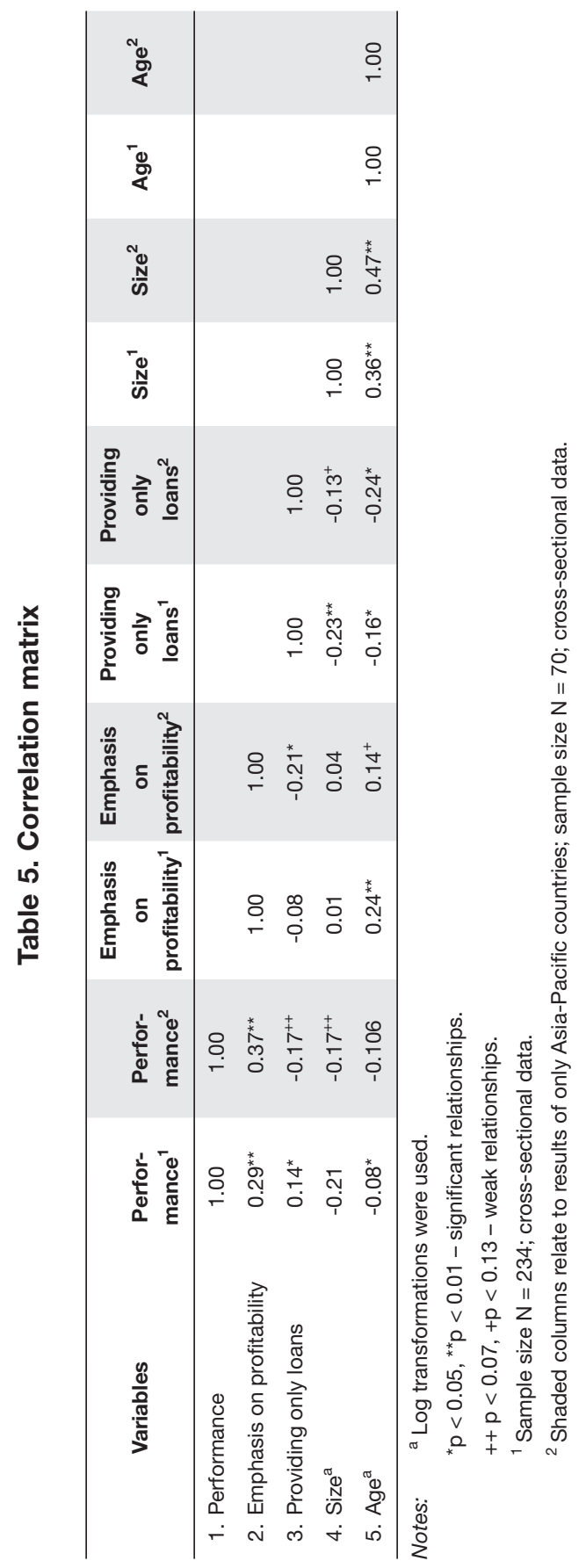




\section{Table 6. Regression results ${ }^{\mathrm{a}}$ of equation (1)}

\begin{tabular}{|c|c|c|c|c|c|c|}
\hline Independent variables & $\begin{array}{l}\text { Unstan- } \\
\text { dardized } \\
\text { coefficient }{ }^{1} \\
\text { (B) }\end{array}$ & $\begin{array}{l}\text { Unstan- } \\
\text { dardized } \\
\text { coefficient }^{2} \\
\text { (B) }\end{array}$ & $\begin{array}{c}\text { Standard } \\
\text { error }^{1}\end{array}$ & $\begin{array}{c}\text { Standard } \\
\text { error }^{2}\end{array}$ & $\begin{array}{l}\text { Standard- } \\
\text { ized } \\
\text { coefficient }^{1} \\
\text { (ß) }\end{array}$ & 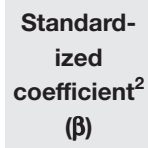 \\
\hline Emphasis on profitability & 1.25 & 1.42 & 0.26 & 0.47 & $0.31^{\star *}$ & $0.35^{\star \star}$ \\
\hline Providing only loans & 0.31 & -0.21 & 0.14 & 0.28 & $0.15^{\star}$ & -0.09 \\
\hline Size $^{b}$ & 0.03 & 0.13 & 0.05 & 0.09 & 0.03 & 0.17 \\
\hline $\mathrm{Age}^{\mathrm{b}}$ & -0.18 & -0.07 & 0.11 & 0.23 & $-0.11^{*}$ & -0.04 \\
\hline
\end{tabular}

Notes: $\quad{ }^{a}$ Dependent variable - performance.

${ }^{b}$ Log transformations were used.

${ }^{*} p<0.05,{ }^{* *} p<0.01-$ significant relationships.

1 Sample size $\mathrm{N}=234$; cross-sectional data.

${ }^{2}$ Shaded columns relate to results of only Asia-Pacific countries; sample size $N=70$; cross-sectional data.

Table7. Relationship between age,${ }^{a}$ size $^{\mathrm{a}}$ and providing only loans

\begin{tabular}{lccc}
\hline \multicolumn{1}{c}{ Regression models } & $\boldsymbol{\beta}$ & Value of $\boldsymbol{\beta}_{\mathrm{ij}}{ }^{1}$ & Value of $\boldsymbol{\beta}_{\mathrm{ij}}{ }^{2}$ \\
\hline Providing only loans $=\beta_{01}+\beta_{11}$ Age $+\mathrm{e}_{1}$ & $\beta_{11}$ & $-0.16^{\star \star}$ & $-0.23^{\star}$ \\
Size $=\beta_{02}+\beta_{12}$ Age $+\mathrm{e}_{2}$ & $\beta_{12}$ & $0.36^{\star \star}$ & $0.47^{\star \star}$ \\
Providing only loans $=\beta_{03}+\beta_{13}$ Age $+\beta_{23}$ Size $+\mathrm{e}_{3}$ & $\beta_{13}$ & -0.11 & $-0.22^{*}$ \\
& $\beta_{23}$ & $-0.19^{\star \star}$ & -0.24 \\
\hline
\end{tabular}

Notes: $\quad{ }^{a}$ Log transformations were used.

${ }^{*} \mathrm{p}<0.05,{ }^{* *} \mathrm{p}<0.01-$ significant relationships.

${ }^{1}$ Sample size $\mathrm{N}=234$; cross-sectional data.

2 Shaded columns relate to results of only Asia-Pacific countries; sample size $N=70$; cross-sectional data. 


\section{Table 8. Relationship between age, ${ }^{a}$ emphasis on profitability and performance}

\begin{tabular}{lccl}
\hline \multicolumn{1}{c}{ Regression models } & $\boldsymbol{\beta}$ & $\begin{array}{l}\text { Value } \\
\text { of } \boldsymbol{\beta}_{\mathrm{ij}}{ }^{1}\end{array}$ & $\begin{array}{l}\text { Value } \\
\text { of } \boldsymbol{\beta}_{\mathrm{ij}}{ }^{2}\end{array}$ \\
\hline Performance $=\beta_{01}+\beta_{11}$ Age $+\mathrm{e}_{1}$ & $\beta_{11}$ & $-0.08^{\star}$ & 0.11 \\
Emphasis on profitability $=\beta_{02}+\beta_{12}$ Age $+\mathrm{e}_{2}$ & $\beta_{12}$ & $0.24^{\star \star}$ & $0.14^{++}$ \\
Performance $=\beta_{03}+\beta_{13}$ Age $+\beta_{23}$ emphasis on profitability $+\mathrm{e}_{3}$ & $\beta_{13}$ & $-0.12^{\star}$ & 0.06 \\
& $\beta_{23}$ & $0.30^{\star \star}$ & $0.36^{\star \star}$ \\
\hline
\end{tabular}

Notes: $\quad{ }^{a}$ Log transformations were used.

${ }^{*} \mathrm{p}<0.05,{ }^{* *} \mathrm{p}<0.01-$ significant relationships.

$++p<0.07,+p<0.13-$ weak relationships.

${ }^{1}$ Sample size $\mathrm{N}=234$; cross-sectional data.

2 Shaded columns relate to results of only Asia-Pacific countries; sample size $\mathrm{N}=70$; cross-sectional data.

The comparisons of results show that most of the findings in the main analysis are relevant to MFIs in the Asia-Pacific region. Some results show weak relationships between the variables $(p<0.07$ and $p<0.13$ ). This is due to the significant decrease in the sample size, which reduces the power and hence, the ability to pick up significant relationships. (Note that the sample size of 70 relating to the Asia-Pacific region is less than one third of the original sample size of 234). The conclusions that can be drawn from the relationships shown in the comparison tables can be summarized as follows.

\section{Strong relationships $(p<0.5)$}

- $\quad$ MFls grow in size with Age

- With age MFIs gain experience and go into product diversification

- Product diversification prompts MFls to focus more on profits

- Emphasis on profits helps MFIs to perform better in alleviating poverty.

\section{Weak relationships $(p<0.13)$}

- When MFls grow in size, they go into product diversification $(p<0.13)$ and perform better in alleviating poverty compared to smaller MFIs $(p<0.07)$.

- Mature MFls focus more on profits $(p<0.13)$.

- MFIs that go into product diversification perform better in alleviating poverty ( $p<0.07)$. 
It may be noted that there is one interesting change in the results when compared to those of the main sample. The Asia-Pacific sample shows that product diversification improves the performance while the main sample shows the opposite. This is a fact that can be argued from both sides. Obviously, the strong negative effect of the main sample may have overridden the positive effect in the small sample.

A detail discussion of the above results and the conclusions that can be drawn from the study are given in the next section.

\section{v. DISCUSSION AND CONCLUSION}

The main objective of this research was to study whether MFIs change their management policies with regard to emphasis on profitability and product diversification when they mature and expand in size, and whether such changes improve their performance with regard to poverty alleviation. This was done by analysing the relationships between five variables of MFls that change over time: age; size; product diversification; emphasis on profitability; and performance, in relation to alleviation of poverty in a sustainable manner. An understanding of how product diversification and emphasis on profitability can affect the performance of MFIs in relation to alleviation of poverty in a sustainable manner is useful for managers of MFls when setting organizational policies and also for the donors who "may" be influencing the policies of MFls when they inject hundreds of millions of dollars into the microfinancing sector.

Data relating to 234 MFIs from 63 countries around the world, including countries in the Asia-Pacific region, were used in the study. The results of the main analysis conducted on these 234 MFIs given in section IV can be summarized and shown, as indicated in figure 5 .

First, "age" $\left(\mathrm{H}_{1}\right)$, "providing only loans" or "not going into product diversification" $\left(\mathrm{H}_{3}\right)$ and "emphasis on profitability" $\left(\mathrm{H}_{4}\right)$ has a significant direct impact on the "performance" of MFIs in relation to alleviation of poverty (table 2 and figure 5).

The relationship between "age" and "performance" $\left(H_{1}\right)$ is a negative one. This concurs with previous studies in other industries (Wagner 1995; Glancey 1998; Wijewardena and Tibbits, 1999; Almus and Nerlinger, 1999). Microfinancing is different from traditional banking and is a new industry that MFIs learn as they mature. Therefore, there is a tendency for newly established MFIs to learn from the mistakes made by mature ones. While the previous studies mentioned above were in different industries, the situation of microfinancing is probably similar to the post-Soviet Union companies of the Russian Federation that had to learn to operate in a market 
Figure 5. Model showing all the significant relationships

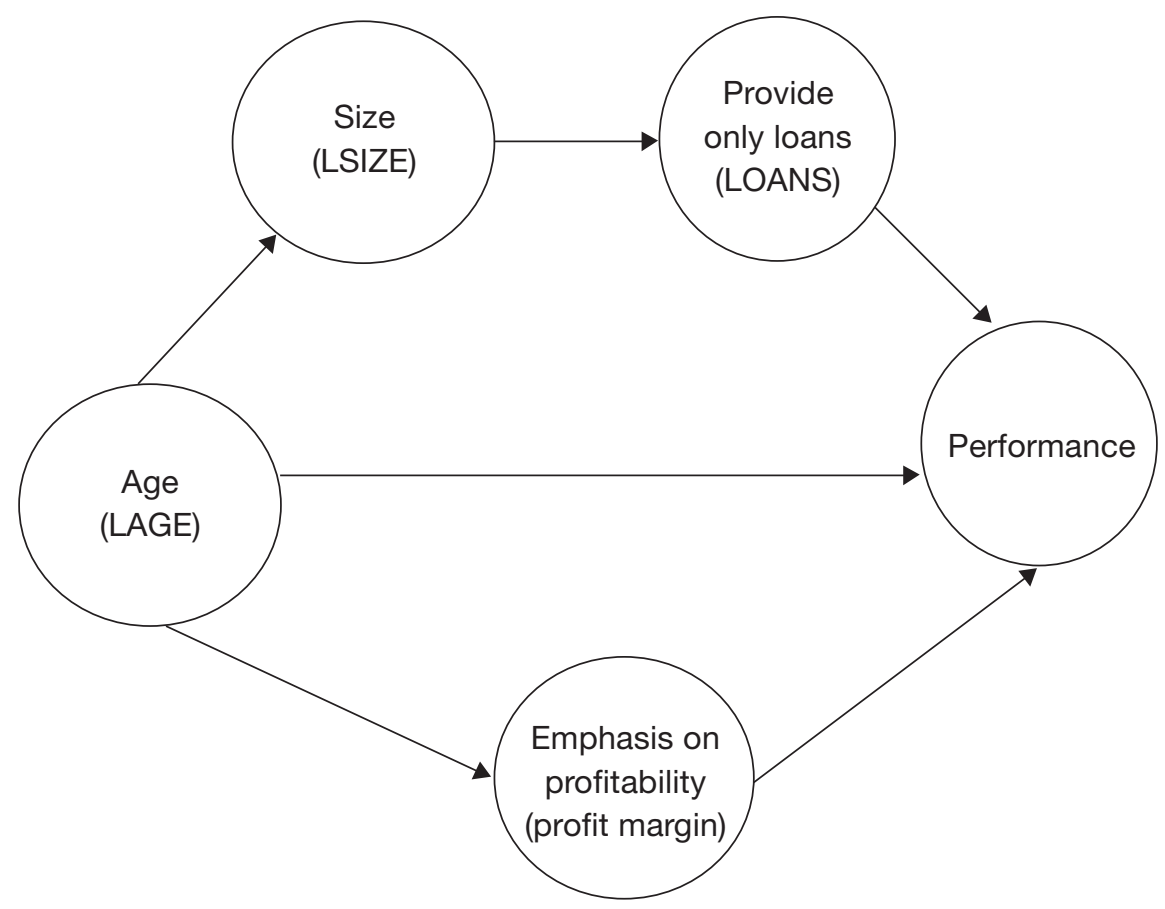

economy, which was completely new to them. Liuhto (2001), who studied the change in organizational performance of more than 1,000 post-Soviet Union companies found that "younger organizational age is linked to positive change in performance".

The results also indicate that "emphasis on profitability" has a direct impact on "performance" $\left(\mathrm{H}_{4}\right)$. This result is not surprising because focusing on profits would encourage MFls to be more efficient in their operations and also not to depend on subsidies from donors. The surpluses they make can be used to help more poor people, which improves their efforts to alleviate poverty. Therefore, the results of this study support those who argue for MFls to take a "commercial approach" (Christen, 1998; Robinson, 1998; Schmidt and Zeitinger, 1994) against those that advocate a "welfare approach" (Marcus, Porter and Harper, 1999; CGAP, 2001).

The direct positive impact of "providing only loans" (not diversifying) on "performance" $\left(\mathrm{H}_{3}\right)$ is not expected. (However, this was not the case for MFls in the Asia-Pacific countries, which is discussed later). In commercial companies, diversification provides stability and reduces the risk of relying on one product 
because every product has a limited life cycle. Therefore, it is expected that the diversified organizations will perform better, as argued by many scholars. However, as indicated by the results, this argument is not valid in microfinancing. The main reason for this is probably because of the large demand for microfinancing services compared to the supply (seller's market), which reduces the need for MFIs to diversify into other products or services for their survival. Offering loans to the poor without any security will be desired until global poverty is eliminated, which may take decades or even centuries.

Another contributing factor for this result may be that the gains from diversification, such as saving or insurance, could be far less compared with the costs. The savings deposit of the poor may be very small unlike in banks to yield an adequate return to cover administration costs, including costs of complying with regulations imposed by reserve banks and government authorities for taking deposits. This negative impact on the cash flow leaves fewer funds for MFls to help more poor people, thus, reducing their performance in relation to poverty alleviation. Another reason may be that loan facilities are more important for the poor compared to savings facilities to improve their income levels. For example, attaining a loan is more difficult for the poor than having a place or a facility to save your money after earning it. However, further research is needed in this area to confirm this.

As shown in table 2, Hypothesis $\mathrm{H}_{2}$ was not supported. "Size" did not have a direct impact on "performance" $\left(\mathrm{H}_{2}\right)$. Therefore, the results of this study support Gibrat's Law (1931) and challenge the findings of studies by Evans (1987), Hall (1987) and Almus and Nerlinger (1999), which found a significant and negative relationship between those two variables. It concurs with Audretsch and others, (2002), which found that Gibrat's Law is valid for the service industry. Microfinancing can be considered to be a type of service.

After analysing the direct impact of age, size, emphasis on profitability and providing only loans on the performance, the indirect and mediating effects among these variables were reviewed. Two relationships $\left(R_{1}\right.$ and $R_{2}$ above) were analysed.

In $R_{1}$, the relationships between age, size and providing only loans were examined. Results show that age has a positive effect on the size (ref $\beta_{12}$ in table 3 ), which is illustrated in figures 3 and 5 . This was expected because the demand for microfinancing is much higher than the supply, as explained earlier. This means that over time. MFIs grow in size. This result supports the findings of other studies in which the average firm size increased with age (Hutchinson, Patrick and Walsh, 2010; Cabral and Mata, 2003). 
It was also shown that age had a negative effect on "providing only loans" (ref $\beta_{11}$ in table 3 ). This means that mature MFIs diversify into other products and services, such as savings accounts and insurance. This concurs with Farjourn (1994), Montgomery and Hariharan (1991), Chang (1996) and Ingram and Baum (1997), who argue that experience and knowledge gained due to age enhances the ability of organizations to diversify into other products. It was also found that "size" has a negative effect on "providing only loans" (ref $\beta_{23}$ in table 3 ). In other words, when MFIs expand, they diversify into other products in addition to loans (product diversification). This is shown in figures 3 and 5 and is supported by previous studies done in other industries, namely Dass, 2000; Wheeler and others, 1999; Donaldson, 1982; Dawley, Hoffman and Brockman (2003); and Silverman and Castaldi, 1992. However, when the effect of size and age is controlled, there is no significant impact on "providing only loans" (note that $\beta_{13}$ in table 3 is not significant). Therefore, the impact of "age" on "providing only loans" flows entirely through "size", which acts as a mediating variable between "age" and "providing only loans" (figures 3 and 5). The conclusion to be drawn here is that age and size have an impact on product diversification, similar to findings of other studies mentioned above. However, the effect of age on diversification in microfinancing is due to its influence on size.

In the last stage of the data analysis, the relationships between "age", "emphasis on profitability" and "performance" are reviewed $\left(R_{2}\right)$. The results show a significant positive relationship between "age" and "emphasis on profitability" ( $\beta_{12}$ in table 4 and figure 5), which means that mature MFIs place greater emphasis on profits and take a commercial approach rather than a welfare approach. This supports the argument of Schmidt (2010) that most MFIs start as not-for-profit organizations and gradually convert to commercial enterprises. Some, such as Bancosol in Bolivia, have even gone to the extent of transforming into banks. This "mission drift" found in this study has been confirmed by case studies done in different countries (Drake and Rhyne, 2002; Rhyne, 2001; Sriram, 2010; Khan, 2010). One of the main reasons for mature MFIs to focus on profits could be the competition for limited donor funds and/ or donor pressure, as explained by Epstein and Yuthas (2010). Thus, MFIs may be realizing the need to generate their own funds rather than rely on subsidies from donors.

Because both emphasis on profitability and age have significant direct impacts on performance (see table 2), and that age has a significant impact on emphasis on profitability ( $\beta_{12}$ in table 4 ) as shown in figure 4 , the possible mediating effect of emphasis on profitability between age and performance was tested by using the Baron and Kenny (1986) method. The results shown in table 4 confirm that after controlling for the effects of emphasis on profitability, age has a significant impact on performance $\left(\beta_{13}\right.$ in table 4$)$. This means that any mediating effect of emphasis on 
profitability on the relationship between age and performance is insignificant, although there is a statistically significant relationship between age and emphasis on profitability. The relationship between these three variables can be confirmed, as shown in figures 4 and 5.

\section{Relevance of the findings to the Asia-Pacific region and policy implications}

The analysis conducted on the $234 \mathrm{MFls}$ around the world was repeated on 70 MFIs in the sample located in the Asia-Pacific region. This was carried out mainly to compare and assess the applicability of the results of the main analysis to the AsiaPacific region. The results and the analysis conducted on the Asia-Pacific region given in section IV, under Relevance of the main results to the Asia-Pacific region, indicate that the findings of the main study are applicable to the region. However, there is one exception. The main study indicates that product diversification has a negative effect on the performance in relation to alleviation of poverty, while the analysis on the sample of MFls in the Asia-Pacific region shows this to be the complete opposite (positive effect). Therefore, smaller MFIs that focus on only providing loans (no product diversification) perform better than mature large MFIs in general, while in the Asia-Pacific region, the large mature MFls that adopt product diversification perform better than those that only provide loans. The impact of product diversification on MFIs can be argued both ways as discussed earlier. The small size of savings deposits placed in MFIs, which makes them not financially viable, is believed to be the main reason for the negative impact. It may be that the savings deposits of MFIs in the Asia-Pacific region are generally larger compared to those in other parts of the world. The comparatively higher economic growth in some developing countries in the Asia-Pacific region may be one reason. However, further research is needed in this area.

Policy implications to MFIs in the Asia-Pacific region and the rest of the world related to the findings of this study is shown in figure 5. In conclusion, as MFIs mature, they tend to become larger. During this transformation, there is a shift in their management policies to adopt product diversification and focus more on profitability. These two changes have significant impacts on the performance of MFIs with regard to poverty alleviation. While emphasis on profitability has a positive effect on MFIs, the impact of product diversification depends on the region. In the Asia-Pacific region product diversification has had a positive impact on poverty alleviation. The mature large MFls that adopt product diversification have performed better in alleviating poverty compared to those that have only focused on providing loans. In the other parts of the world, product diversification has had a negative impact on the performance with regard to poverty alleviation. Outside the Asia-Pacific region, young MFIs that have only focused on providing loans without product diversification have performed better than mature MFIs in alleviating poverty. 
The findings of this study make a significant contribution to the existing knowledge in the microfinancing area. It improves the understanding of the transformations that MFIs go through over time in two key areas that contribute to their performance in relation to alleviation of poverty. No other empirical studies taking a global perspective (63 countries) or one that focuses on the Asia-Pacific region have been done previously in this area. Key lessons learned are that MFIs shift to focusing on profits and product diversification as they mature and expand in size. Emphasizing profitability improves the performance of MFIs in their poverty alleviation efforts. However, adopting product diversification has to be done with extreme caution after careful consideration. The results show that product diversification has a positive effect on the performance of MFIs in relation to alleviation of poverty in the Asia-Pacific region, but it has a strong negative impact in other parts of the world. These key lessons have significant policy implications for donors to and managers of MFIs that operate in countries in the Asia-Pacific region and in the rest of the world.

In addition to policy implications, the study also makes a contribution to academic research. It supports and challenges the results of previous studies on, for example, age, size and product diversification, in other industries compared to when applied to microfinancing. For example, this study reveals that Gibrat's Law (1931) is applicable to microfinancing. Gibrat's Law states that there is no relationship between firm size and performance.

\section{Limitations and future research}

There are a number of limitations to this study. First, it has not looked at the causes that have prompted MFIs to change their policies relating to the emphasis on profitability and product diversification. Donor pressure or lack of donor funding are possible causes. However, the study fails to include these variables in the model; it only confirms that as MFls mature and expand in size, their policies towards these two key areas change.

Second, the data relate to a one-year period. The effect of some variables on others may have a time lag that exceeds a one-year period. Such impacts cannot be found in this study. Third, other than the factors considered in this study, there may be other variables that significantly affect the performance of MFIs. Examples of this in the type of empirical analysis used for this study are omitted variables, endogeneity and reverse causality may are examples of this. Therefore, future research can be carried out to improve this model with more variables that change over time using data that cover a number of years for longitudinal studies. The possible reasons for diversification to have a positive effect on the performance of MFIs in the Asia-Pacific region in contrast to the negative effect in other parts of the world is also another area 
that opens opportunities for future research. Although costs and size of the deposits are speculated as the cause, it needs to be further investigated.

Some of the MFIs in the sample may be adopting Islamic Microfinancing (IMFI) practices. However, in the data, this difference has not been identified or captured. IMFIs take a welfare approach and unlike conventional MFIs, they do not charge any interest for the loans granted to the poor. However, a service fee is charged to cover the operational costs without any profit. It may be interesting to compare the above relationships of IMFIs with those of the conventional MFIs. This is another area with immense potential for future research. 


\section{REFERENCES}

Adams, Dale W. (1998). Altruistic or Production Finance? A Donor's Dilemma. Brookfield, Vermont, U.S.A: Ashgate Publishing.

Aitken, Rob (2010). Ambiguous incorporations: microfinance and global governmentality. Global Networks, vol. 10, No. 2, pp. 223-243.

Almus, Matthias, and Eric A. Nerlinger (1999). Growth of new technology based firms: which factors matter? Small Business Economics, vol. 13, No. 2, pp. 141-154.

Asian Development Bank (ADB) (2000). Finance for the Poor: Microfinance Development Strategy. Manila.

Audretsch, D.B., and others (2002). Gibrat's law, are the services different? Review of Industrial Organization, vol. 24, No. 3, pp. 301-324.

Baker, Douglas D., and John B. Cullen (1993). Administrative reorganisation and configurational context: the contingent effects of age, size, and change in size. Academy of Management Journal, vol. 36, No. 6, pp. 1251-1277.

Baron, Reuben M., and David A. Kenny (1986). The moderator-mediator variable distinction in social psychological research: conceptual, strategic, and statistical considerations. Journal of Personality and Social Psychology, vol. 51, No. 6, pp. 1173-1182.

Bateman, Milford (2010). Why Doesn't Microfinance Work? The Destructive Rise of Local Neoliberalism. London: Zed Books.

Bruck, Connie (2006). Millions for millions, The New Yorker, 30 October.

Cabral, Luis M.B., and Jose Mata (2003). On the evolution of the firm size distribution: facts and theory. American Economic Review, vol. 93, No. 4, pp. 1075-1090.

Chang, Seajin (1996). An evolutionary perspective on diversification and corporate restructuring. Entry, exit, and economic performance during 1981-89. Strategic Management Journal, vol. 17 , No. 8 , pp. 587-611.

Christen, Robert Peck (1998). Keys to financial sustainability. In Strategic Issues in Microfinance. Mwangi S. Kimenyi and others, eds. Brookfield, Vermont, U.S.A.: Ashgate Publishing.

Consultative Group to Assist the Poor (CGAP) (2001). Commercialisation and mission drift, the transformation of microfinance in Latin America. CGAP Occasional Paper, No. 5. Washington, D.C.: World Bank.

(2002). Microfinance and the Millennium Development Goals. Donor Brief, No. 9. Washington, D.C.: World Bank.

(2003). Microfinance Consensus Guidelines: Definitions of Selected Financial Terms, Ratios, and Adjustments for Microfinance. Washington, D.C.: World Bank.

Dass, Parshotam (2000). Relationship of firm size, initial diversification, and internationalization with strategic change. Journal of Business Research, vol. 48, No. 3, pp. 135-146.

Dawley, David D., James J. Hoffman, and Erich N. Brockman (2003). Do size and diversification type matter? An examination of post-bankruptcy outcomes. Journal of Managerial Issues, vol. 15 , No. 4, pp. 413-429.

Donaldson, Lex (1982). Divisionalization and size: a theoretical and empirical critique. Organization Studies, vol. 3, No. 4, pp. 321-337. 
Drake, Deborah, and Elisabeth Rhyne, eds. (2002). The Commercialization of Microfinance: Balancing Business and Development. Bloomfield, Connecticut, U.S.A.: Kumarian Press.

Dunford, Chrisopher (2001). Building better lives: sustainable integration of microfinance and education in health, family planning and HIV/AIDS prevention for the poorest entrepreneurs. Journal of Microfinance, vol. 3, No. 2, pp. 1-25.

Eikenberry, Angela M., and Jodie Draper Kluver (2004). The marketization of the nonprofit sector: civil society at risk? Public Administration Review, vol. 64, No. 2, pp.132-140.

Epstein, Marc J., and Kristi Yuthas (2010). Mission impossible: diffusion and drift in the microfinance industry. Sustainability Accounting, Management and Policy Journal, vol. 1, No. 2, pp. 201-221.

Evans, David S. (1987). Tests of alternative theories of firm growth. Journal of Political Economy, vol. 95, No. 4, pp. 657-674.

Farjourn, Moshe (1994). Beyond industry boundaries: human expertise, diversification and resourcerelated industry groups. Organization Science, vol. 5, No. 2, pp. 185-199.

Fernando, Jude L. (2006). Microcredit and empowerment of women: blurring the boundary between development and capitalism. In Microfinance: Perils and Prospects, Jude L. Fernando, ed. New York: Routledge Publishing.

Foundation for Development Corporation (1992). Banking with the Poor; Case Studies Prepared by Leading Asian Banks and Non Governmental Organisations. Brisbane, Australia.

Geiger, Scott W., and Luke H. Cashen (2007). Organizational size and CEO compensation: the moderating effect of diversification in downscoping organisations. Journal of Managerial Issues, vol. 19, No. 2, pp. 233-252.

Gibrat, R. (1931). Les Inégalités Economiques. Paris: Editionos Sirey. In French.

Glancey, Keith (1998). Determinants of growth and profitability in small entrepreneurial firms. International Journal of Entrepreneurial Behaviour \& Research, vol. 4, No. 1, pp. 18-27.

Hall, Browyn H. (1987). The relationship between firm size and firm growth in the US manufacturing sector. Journal of Industrial Economics, vol. 35, No. 4, pp. 583-606.

Hulme, David, and Paul Mosley (1996). Finance Against Poverty. London: Routledge Publishing.

Hutchinson, John, Jozef Konings Patrick, and Paul Walsh (2010). The firm size distribution and interindustry diversification. Review of Industrial Organization, vol. 37, No. 2, pp. 65-82.

Ingram, Paul, and Joel A.C. Baum (1997). Opportunity and constraint: organizations' learning from the operating and competitive experience of industries. Strategic Management Journal, vol. 18, No. S1 (July), pp. 75-98.

Jiang, Fuxiu (2006). Determinants of diversification by listed firms in China. Frontiers of Business Research in China, vol. 2, No. 2, pp. 170-186.

Khan, Ashfaq Ahmad (2010). Commercialization of microfinance - Is the sector losing its identity by evading its original social service responsibility? Social and Environmental Accountability Journal, vol. 28, No. 2, pp. 78-90.

(2011). Dictating change, shouting success: Where is accountability? Australasian Accounting, Business and Finance Journal, vol. 5, No. 4, pp. 85-99. 
Khandker, Shahidur, and Baqui Khalily (1996). The Bangladesh Rural Advancement Committee's Credit Programmes: performance and sustainability. Discussion Paper, No. 324. Washington, D.C.: World Bank.

Khandker, Shahidur R., Zahed Khan, and Baqui Khalily (1995). Sustainability of a government targeted credit program: evidence from Bangladesh. Discussion Paper, No. 316. Washington, D.C.: World Bank.

Liuhto, Karl (2001). How much does size, age, or industry membership matter in transition? Studying change in organizational behavior in almost 1,000 post-Soviet Companies. Problems of Economic Transition, vol. 43, No. 12, pp. 6-49.

Marcus, Rachel, Beth Porter, and Caroline Harper (1999). Money matters: understanding microfinance. Save the Children Working Paper, No. 19. London: Save the Children Foundation Press.

Mintzberg, Henry, and James Brian Quinn (1998). Readings in the Strategy Process. Upper Saddle River, New Jersey: Prentice Hall International.

Montgomery, Cynthia A., and S. Hariharan (1991). Diversified expansion by large established firms. Journal of Economic Behavior and Organization, vol. 15, No. 1, pp. 71-87.

Mort, Gillian Sullivan, Jay Weerawardena, and Kashonia Carnegie (2003). Social entrepreneurship; towards conceptualization. International Journal of Nonprofit and Voluntary Sector Marketing, vol. 8, No 1, pp. 76-88.

Nanayakkara, Gemunu (2012). Measuring the performance of microfinancing institutions; a new approach. South Asia Economic Journal, vol. 13, No. 1, pp. 89-104.

Owens, John V. and Sylvia B. Wisniwiski (1999). Microsavings: what we can learn from informal savings. Presentation. Available from www.wiwi.uni-frankfurt.de/finance/schmidt/ndf/ndf_3/ thu_rural_owens_wisniwski_pres.pdf.

Piergiovanni, Roberta, and others (2002). Gibrat's law and the firm size/firm growth relationship in Italian services. Timbergen Institute Discussion Paper. Rome: Department of National Accounts \& Statistics of Italy.

Pitt, Mark, and Shahidur R. Khandker (1996). Household and intra-household impact of the Grameen Bank and similar targeted credit programs in Bangladesh. Discussion Paper, No. 320. Washington, D.C.: World Bank.

Reed, Larry, and Jan Maes (2012). State of the Microcredit Summit Campaign Report 2012. Available from www.microcreditsummit.org/resource/46/state-of-the-microcredit-summit.html.

Rhyne, Elisabeth (2001). Mainstreaming Microfinance: How Lending to the Poor Began, Grew and Came of Age in Bolivia. Boulder, Colorado, U.S.A.: Kumarian Press.

Robinson, M. (1998). Microfinance: the Paradigm Shift from Credit Delivery to Sustainable Financial Intermediation. Brookfield, Vermont, U.S.A.: Ashgate Publishing.

Robinson, Marguerite S. (2001). The Microfinance Revolution: Sustainable Finance for the Poor. Washington, D.C.: World Bank.

(2002). The Microfinance Revolution, vol. 2, Lessons from Indonesia. Washington, D.C.: World Bank.

Rogaly, Ben (1996). Microfinance evangelism, 'destitute women', and the hard selling of a new antipoverty formula. Development in Practice, vol. 6, No. 2, pp. 100-112. 
Schmidt, Reinhard H. (2010). Microfinance commercialization and ethics. Poverty and Public Policy, vol. 2, No. 1, pp. 99-137.

Schmidt, Reinhard H., and Claus-Peter Zeitinger (1994). Critical Issues in Micro-business Finance and the Role of Donors. In Strategic Issues in Microfinance. Mwangi S. Kimenyi and others, eds. Brookfield, Vermont, U.S.A.: Ashgate Publishing. Burlington: Ashgate Publishing.

Silverman, Murray, and Richard M. Castaldi (1992). Antecedents and propensity for diversification: a focus on small banks. Journal of Small Business Management, vol. 30, No. 2, pp. 42-52.

Sriram, M.S. (2010). Commercialisation of microfinance in India: a discussion on the emperor's apparel. Economic and Political Weekly, vol. 45, No. 24, pp. 65-73.

Valenzuela, Liza (2002). Getting the recipe right, the commercialisation of microfinance. In The Commercialization of Microfinance: Balancing Business and Development, Deborah Drake and Elisabeth Ryne, eds. Boulder, Colorado, U.S.A.: Kumarian Press.

Vogel, Robert C. (1984). Savings mobilization: the forgotten half of rural finance. In Undermining Rural Development with Cheap Credit, Douglas Graham and Dale W. Evans, eds. Boulder, Colorado, U.S.A.: Westview Press.

(1998). Other People's Money: Regulatory Issues Facing Microenterprise Finance Programs. Washington, D.C.: Communications Corporation.

Wagner, Joachim (1995). Exports, firm size, and firm dynamics. Small Business Economics, vol. 7 , No. 1, pp. 29-39.

Wheeler, J.R.C., and others (1999). Financial and organisational determinants of hospital diversification into subacute care. Health Services Research, vol. 34, No. 1, pp. 61-81.

Wijewardena, Herma, and Garry E. Tibbits (1999). Factors contributing to the growth of small manufacturing firms: data from Australia. Journal of Small Business Management, vol. 37, No. 2, pp. 88-96.

World Bank (2009). The World Bangkok Annual Report 2009: the Year in Review. Washington, D.C.

Yaron, Jacob (1992). Assessing development finance institutions. A public interest analysis. Policy Research Working Paper, No. 174. Washington, D.C.: World Bank.

Yasuda, Takihido (2005). Firm growth, size, age and behavior in Japanese manufacturing. Small Business Economics, vol. 24, No. 1, pp. 1-15.

Yunus, Muhammad, and Alan Jolis (2001). Banker to the Poor: the Autobiography of Muhammad Yunus. New York: Oxford University Press. 